\title{
Preterm Nutrition
}

\author{
Nishani Lucas ${ }^{1}$ \\ Sri Lanka Journal of Child Health, 2014: 43(1): 41-52
}

(Key words: Preterm nutrition)

More and more preterm babies weighing $600-700 \mathrm{~g}$ are surviving in Sri Lanka with improvements in the obstetric and neonatal services. Abnormal neurodevelopment is one of the major comorbidities in these preterm survivors. Inadequate early postnatal nutrition appears to result in abnormal neurodevelopment ${ }^{1}$. Therefore, provision of good nutrition becomes vital in striving for better neurodevelopmental outcomes. It is not possible to define the nutritional requirements without defining optimal growth for preterm very low birth weight (VLBW) babies. However, there is no model for determining the optimal qualitative and quantitative growth in these babies ${ }^{2}$. Inadequate nutrients have been shown to cause short stature, growth failure, neuronal deficits and poor behavioural and cognitive outcomes ${ }^{3}$. The goal of nutritional support in preterm infants was thought to be achieving a postnatal growth rate similar to that of a normal fetus at the same postconceptual age ${ }^{4}$.

Preterm birth causes abrupt premature interruption to the nutrients provided by the placenta. An "aggressive" nutritional approach has been proposed in order to minimize this interruption. The best way to provide nutrition to newborn infants is breast milk (BM) feeding ${ }^{5}$. However, oral feeds often do not provide adequate nutrition until full feeds are given, which would take a minimum of 3 to 5 days when the mother's milk volume increases as colostrum is replaced by the copious milk secretion. Therefore, parenteral nutrition $(\mathrm{PN})$ should be started soon after birth to achieve neonatal growth rates similar to those of the normal fetus ${ }^{1}$. Early PN has been shown to improve short term outcomes like weight on discharge without increasing the morbidity or mortality ${ }^{6}$.

\section{Energy requirement}

Preterm infants have low energy reserves due to the fact that they are born before fat and glycogen reserves have accumulated. Energy requirements

${ }^{1}$ Consultant Neonatologist, Professorial Unit, De Soysa Hospital for Women, Senior Lecturer, Department of Paediatrics, Faculty of Medicine, University of Colombo, Internationally Board Certified Lactation Consultant (IBCLC) depend on the stage of development and are higher at 24 weeks compared to 38 weeks gestational age. They are affected by resting energy expenditure (EE) and growth. Resting EE, estimated to be $50 \mathrm{kcal} / \mathrm{kg} /$ day, is affected by sleep state and activity levels, environmental factors such as thermoregulation and demands for tissue synthesis but does not vary much with gestational age. Synthesis of new tissue (growth and repair) requires more energy and is affected by protein and energy intake. Estimated average energy requirements for new tissue formation in preterm infants are 4.5-4.9 kcal/g. Major increases in lean and fat mass occur during the third trimester. If the intrauterine average weight gain of $15-17 \mathrm{~g} / \mathrm{kg} / \mathrm{day}$ is to be achieved, $67-83 \mathrm{kcal} / \mathrm{kg} /$ day will be needed in addition to the resting EE. In total, this will come to $120-130 \mathrm{kcal} / \mathrm{kg} /$ day of total energy intake ${ }^{7}$.

\section{Carbohydrate requirement}

Glucose utilization rates (GURs) are twice as high in early gestation as the brain is larger and accounts for nearly all of whole body GUR. Therefore, glucose synthetic rates in preterm infants are much higher at $6-8 \mathrm{mg} / \mathrm{kg} /$ minute compared to term infants who synthesise glucose at a rate of 3-5 $\mathrm{mg} / \mathrm{kg} / \mathrm{minute}^{8} .10 \%$ dextrose when administered at $60-80 \mathrm{ml} / \mathrm{kg} /$ day will provide glucose at a rate of 4$6 \mathrm{mg} / \mathrm{kg} / \mathrm{min}$ (see Table 3 )

\section{Lipid requirement}

Lipid is a good source of energy because of its high energy-density ( $1 \mathrm{~g}$ of fat provides $9 \mathrm{kcal}$ compared to $1 \mathrm{~g}$ of carbohydrate or $1 \mathrm{~g}$ of protein providing 4 kcal). Lipids also provide essential fatty acids (EFAs) which are required for brain development. EFA deficiency can develop within the first 72 hours of life and can be avoided by giving at least $0.5-1 \mathrm{~g} / \mathrm{kg} /$ day of intravenous (IV) lipids. EFAs are converted to long chain polyunsaturated fatty acid (PUFA). Docosahexaenoic (DHA) acid is the main fatty acid in the brain. It accumulates in the brain mainly during the last trimester of pregnancy and infants who do not get sufficient amounts of PUFA may have delayed visual development. Lipid infusion rate of $3 \mathrm{~g} / \mathrm{kg} /$ day is well tolerated without adverse effects and provides the required EFAs and energy levels. It may be helpful to restrict lipids in babies with neonatal jaundice above exchange transfusion level, as lipid displaces albumin ${ }^{9,10}$. 


\section{Protein requirement}

Amino acids (AAs) should be provided soon after birth in order to prevent protein breakdown and to promote growth and remodelling of cells, tissues and organs at rates that mimic the growth and body composition of the healthy fetus growing in utero. In order to maintain growth similar to that seen in utero, high AA infusion rates must be provided. Protein must be administered with energy since, in the absence of non-protein energy, protein is oxidized and is not available for protein synthesis. Preterm infants given early IV AA or enteral protein, show evidence of enhanced growth, including head circumference growth and brain size $^{11,12}$. A minimum of $1 \mathrm{~g} / \mathrm{kg} /$ day of protein together with $30 \mathrm{kcal} / \mathrm{kg} /$ day of non-protein energy have been shown to prevent negative nitrogen balance $^{1}$. The normal fetus at mid-gestation is estimated to require $4 \mathrm{~g} / \mathrm{kg} /$ day of protein. Thereby it is estimated that infants $<30$ weeks would require protein $3.5-4.0 \mathrm{~g} / \mathrm{kg} / \mathrm{day}$, those between 30 to 36 weeks would require $2.5-3.5 \mathrm{~g} / \mathrm{kg} / \mathrm{day}$ and infants $>36$ weeks would require $1.5 \mathrm{~g}-2.5 \mathrm{~g} / \mathrm{kg} /$ day $^{13,14,15}$.

Fluid, electrolyte, mineral and vitamin needs

During the first week of life electrolyte needs are relatively low because of free water diuresis. In the first week of life evaporative water loss occurs predominantly from skin and accounts for $10-15 \%$ weight loss. Since this evaporative water loss is more than the fractional sodium excretion, the baby is at high risk of hypernatraemic dehydration in the first week of life. The total fluid requirement starts at about $80-90 \mathrm{ml} / \mathrm{kg} /$ day on Day 1 and increases by $10-20 \mathrm{ml} / \mathrm{kg} /$ day until $150 \mathrm{ml} / \mathrm{kg} /$ day is reached during this time period ${ }^{16}$.

However, in the second week of life the extracellular fluid (ECF) compartment contracts and the aldosterone increases, but the fractional excretion of sodium $(\mathrm{Na})$ remains at $1-3 \%$ due to renal immaturity. Since fractional excretion of $\mathrm{Na}$ remains higher than the evaporative water loss (which is minimal at this point), the baby is at risk of hyponatraemia in the second week and thus warrants $2-3 \mathrm{mmol} / \mathrm{kg} /$ day of $\mathrm{Na}$ and potassium $(\mathrm{K})$ to maintain serum levels in the normal range ${ }^{1,16}$. The baby starts to gain weight by $15-20 \mathrm{~g}$ /day during the third week of life at which point the $\mathrm{Na}$ requirements may double up to $4-6 \mathrm{mmol} / \mathrm{kg} /$ day. The total fluid requirement is $150-200 \mathrm{ml} / \mathrm{kg}$ /day during this time ${ }^{1,16}$.

The total fluid requirement increases from $80 \mathrm{ml}$ $/ \mathrm{kg} /$ day on Day 1 to $180-200 \mathrm{ml} / \mathrm{kg} /$ day on Day 14 . It has been calculated that in the last trimester the daily accretion of calcium $(\mathrm{Ca})$, phosphorus $(\mathrm{P})$ and magnesium $(\mathrm{Mg})$ are 120,70 and $3 \mathrm{mg} / \mathrm{kg} /$ day respectively. Therefore, these minerals should be made available to the baby soon after birth to prevent loss of bone density ${ }^{1}$. Vitamins are essential for growth and development. The infant requires both water-soluble and fat-soluble vitamins soon after birth as neither are stored in significant amounts in the body ${ }^{1}$.

\section{Parenteral nutrition}

Starting PN on Day 1 for babies who are unable to be directly breast fed ( $<32$ weekers, or $<1000 \mathrm{~g}$ ) reduces the incidence of growth failure seen at 36 weeks postnatal age. Therefore, recommendations have been made that at least $1.5 \mathrm{~g} / \mathrm{kg} /$ day of protein should be started within the first 24 hours of life and then increased by $0.5-1 \mathrm{~g} / \mathrm{kg} / \mathrm{day}$ to $3.5-4.0 \mathrm{~g}$ $/ \mathrm{kg} /$ day. Lipids should be provided between 24 and 48 hours of life at $0.5-1.0 \mathrm{~g} / \mathrm{kg} /$ day and increased by $0.5-1.0 \mathrm{~g} / \mathrm{kg} /$ day to $3.0-3.5 \mathrm{~g} / \mathrm{kg} /$ day $^{1}$.

\section{Aggressive early parenteral nutrition}

In the last few years, great attention has been given to high AA supply in VLBW infants from the first day of life in order to avoid catabolism, establish anabolism, achieve in utero protein accretion rates, and promote linear growth ${ }^{5}$. Aggressive early PN involves providing protein $>2.5 \mathrm{~g} / \mathrm{kg} /$ day and $40 \mathrm{kcal} / \mathrm{kg} /$ day on Day 1 with enteral feeds. This has been associated with lesser nutritional deficit and better neurodevelopmental outcomes. However, implementation of this regime will need revision of existing electrolyte recommendations as intracellular cell growth will need $\mathrm{Na}, \mathrm{K}$ and $\mathrm{P}$ which will have to be started on Day $1^{17}$.

\section{Peripheral administration of $\mathrm{PN}$ is safe}

Although historically $\mathrm{PN}$ has been administered via central venous $(\mathrm{CV})$ catheter, in the present day and age it is safer to administer $\mathrm{PN}$ via the peripheral route unless it is anticipated to be used for more than 10 to 14 days. This is due to: $\mathrm{CV}$ catheterisation being the main cause of morbidity and mortality associated with $\mathrm{PN}$, new understanding on prevention of peripheral thrombophlebitis, lower caloric loads in the PN solutions and the use of lipid emulsions ${ }^{18}$. The line carrying the lipid solution should be covered with aluminium foil (obtained from any super market) to protect it from light (exposure to light forms toxic lipid peroxides). $\mathrm{Ca}$ or bicarbonate should not be administered in the same line.

\section{Monitoring while on parenteral nutrition}

The blood sugar needs to be checked 6 to 8 hourly while the fluids are being escalated. Electrolytes should be checked on Day 3 and then twice weekly. Liver function and bone profile $[\mathrm{Ca}, \mathrm{P}$, alkaline phosphatase (ALP)] should be checked weekly. Urine sugar needs to be checked especially in case of hyperglycaemia ${ }^{1}$. 
Complications from parenteral nutrition

Line related complications are sepsis and thromboembolism. Lines used for more than 3 days are associated with increased risk of infiltration and sepsis ${ }^{1}$. The association with liver complications is poorly understood and is seen in babies needing PN over a long period ${ }^{1}$. Hyperglycaemia, described as a complication, is rarely seen in the Sri Lankan setting. It may be because it is very difficult to maintain the GUR of $4 \mathrm{mg} / \mathrm{kg} / \mathrm{min}$, as shown in the example, as PN requires a large volume (less concentrated preparations being available) causing less than optimal/marginal $10 \%$ dextrose volumes being administered most of the time.

Stress in the form of hypotension and thermal instability in the early period may cause an increase in the counter regulatory hormones to elevate the blood sugar level despite marginal GUR $4 \mathrm{mg} / \mathrm{kg} / \mathrm{min}$ being administered intravenously (IV). AAs reduce hyperglycaemia as they increase insulin secretion, whereas lipids promote hyperglycaemia as they inhibit hepatic glucose oxidation and promote gluconeogenesis. Therefore, glucose infusion rates as well as lipid infusion rates may need to be reduced, if faced with hyperglycaemia ${ }^{1}$.
Stopping parenteral nutrition

PN can be stopped when enteral feeds constitute $50 \%$ of the total fluid volume.

Using parenteral nutrition in Sri Lankan setting Although we do not have the luxury of PN premixed bags here in Sri Lanka, we do have IV AA solution (Vaminolact) and IV lipid solution (Lipofundin/ Intralipid 10-20\%). Using the 20\% solution is more advantageous as less volume is required to deliver a given amount of lipid.

No complications were reported following the peripheral administration of $\mathrm{PN}$ in 2 local studies. The first study was done on ventilated neonates at Sri Jayawardenapura General Hospital in 2009/ 2010 where PN was used in 55 babies less than 32 weeks gestation ${ }^{19}$ and the second study was done in 2012/13 at De Soysa Hospital for Women (DSHW) where 30/60 babies less than 34 weeks gestation were given $\mathrm{PN}^{20}$. PN was used for 4 to 5 days in the first study whereas it was stopped in 23/30 (77\%) babies in less than 4 days in the second study.

Below are some guidelines on how these solutions can be used in order to meet the recommendations stated above (Tables 1-4).

Table 1: Guide to prescribe Vaminolact $(0.24 \mathrm{kcal} / \mathrm{ml}, 5.8 \mathrm{~g} / 100 \mathrm{ml})$ in the neonatal unit

\begin{tabular}{|l|c|c|}
\hline Day of life & Protein requirement & Vaminolact volume \\
\hline Day 1 & $1.5 \mathrm{~g} / \mathrm{kg} /$ day & $25 \mathrm{ml} / \mathrm{kg} /$ day \\
\hline Day 2 & $2.0 \mathrm{~g} / \mathrm{kg} /$ day & $34 \mathrm{ml} / \mathrm{kg} /$ day \\
\hline Day 3 & $2.5 \mathrm{~g} / \mathrm{kg} /$ day & $43 \mathrm{ml} / \mathrm{kg} /$ day \\
\hline Day 4 & $3.0 \mathrm{~g} / \mathrm{kg} /$ day & $50 \mathrm{ml} / \mathrm{kg} /$ day \\
\hline Day 5 & $3.5 / \mathrm{kg} /$ day & $60 \mathrm{ml} / \mathrm{kg} /$ day \\
\hline
\end{tabular}

Table 2: Guide to prescribe Intralipid / Lipofundin $(10 \%-1 \mathrm{kcal} / \mathrm{ml}, 20 \%-2 \mathrm{kcal} / \mathrm{ml}$ in the neonatal unit

\begin{tabular}{|l|c|c|c|}
\hline Day of life & Lipid requirement & $\mathbf{1 0 \%}$ & $\mathbf{2 0 \%}$ \\
\hline Day 2 & $1 \mathrm{~g} / \mathrm{kg} /$ day & $5 \mathrm{ml} / \mathrm{kg} /$ day & $10 \mathrm{ml} / \mathrm{kg} /$ day \\
\hline Day 3 & $2 \mathrm{~g} / \mathrm{kg} /$ day & $10 \mathrm{ml} / \mathrm{kg} /$ day & $20 \mathrm{ml} / \mathrm{kg} /$ day \\
\hline Day 4 & $3 \mathrm{~g} / \mathrm{kg} /$ day & $15 \mathrm{ml} / \mathrm{kg} /$ day & $30 \mathrm{ml} / \mathrm{kg} /$ day \\
\hline
\end{tabular}

Table 3: Chart for conversion of glucose rate $(\mathrm{ml} / \mathrm{kg} / 24 \mathrm{~h})$ to $(\mathrm{mg} / \mathrm{kg} / \mathrm{min})$ a/c to strength of solution

\begin{tabular}{|c|c|c|c|c|c|c|}
\hline \multicolumn{2}{|c|}{ Rate of infusion } & \multicolumn{5}{c|}{ Strength of dextrose solution $\mathbf{~ m g} / \mathbf{k g} / \mathbf{m i n}$} \\
\hline $\mathbf{m l} / \mathbf{k g} / \mathbf{2 4 h}$ & $\mathbf{m l} / \mathbf{k g} / \mathbf{h}$ & $\mathbf{5 \%}$ & $\mathbf{1 0 \%}$ & $\mathbf{1 2 . 5 \%}$ & $\mathbf{1 5 \%}$ & $\mathbf{2 0 \%}$ \\
\hline 60 & 2.5 & 2.1 & 4.2 & 5.2 & 6.3 & 8.4 \\
\hline 72 & 3.0 & 2.5 & 5.0 & 6.2 & 7.5 & 10 \\
\hline 80 & 3.3 & 2.8 & 5.6 & 7.0 & 8.4 & 11.2 \\
\hline 100 & 4.2 & 3.5 & 6.9 & 8.6 & 10.7 & 13.8 \\
\hline 120 & 5.0 & 4.2 & 8.3 & 10.4 & 12.5 & 16.6 \\
\hline 150 & 6.3 & 5.2 & 10.4 & 12.5 & 15.6 & 20.8 \\
\hline 180 & 7.5 & 6.2 & 12.5 & 15.6 & 18.7 & 25 \\
\hline 200 & 8.3 & 7 & 13.9 & 17.5 & 20.9 & 28 \\
\hline
\end{tabular}

Table 4: Guide for electrolyte supplementation in the neonatal unit

\begin{tabular}{|l|c|c|c|}
\hline Sodium & $3-4 \mathrm{mmol} / \mathrm{kg} /$ day & $6-8 \mathrm{ml} / \mathrm{kg} /$ day $(3 \% \mathrm{NaCl})$ & $18-24 \mathrm{ml} / \mathrm{kg} /$ day $(0.9 \% \mathrm{NaCl})$ \\
\hline Potassium & $2 \mathrm{mmol} / \mathrm{kg} /$ day & $1 \mathrm{ml} / \mathrm{kg} /$ day $-\mathrm{KCl}$ & \\
\hline
\end{tabular}


In babies $<32$ weeks gestation IV fluids are started at $80 \mathrm{ml} / \mathrm{kg} /$ day as a baseline. Daily weight measurement in the first few days on IV fluids would be the best guide as to whether you need to escalate the total fluid requirement or not.

\section{Example 1}

Initiating fluids for a baby who is $1 \mathrm{~kg}$ at 32 weeks gestation:

Day 1

Total fluids $80 \mathrm{ml} / \mathrm{kg} /$ day $=80 \mathrm{ml} /$ day

Protein $1.5 \mathrm{~g} / \mathrm{kg} /$ day $=$ Vaminolact $25 \mathrm{ml} / \mathrm{kg} /$ day $=$ $25 \mathrm{ml} /$ day

Remaining fluid as $10 \%$ dextrose $=55 \mathrm{ml} /$ day $=55 \mathrm{ml} / \mathrm{kg} /$ day $=$ GUR $4 \mathrm{mg} / \mathrm{kg} / \mathrm{min}$

Enteral feeds, expressed breast milk (EBM) will be given as extra until a regular milk volume is obtained.

Day 2

Total fluids $=100 \mathrm{ml} / \mathrm{kg} /$ day $=100 \mathrm{ml} /$ day

Protein $2 \mathrm{~g} / \mathrm{kg} /$ day $=$ Vaminolact $34 \mathrm{ml} / \mathrm{kg} /$ day $=$ $34 \mathrm{ml} /$ day

Lipid $1 \mathrm{~g} / \mathrm{kg} /$ day $=$ Lipofundin $10 \%-10 \mathrm{ml} / \mathrm{kg} /$ day $=10 \mathrm{ml} /$ day

Remaining fluid as $10 \%$ Dextrose $=56 \mathrm{ml} / \mathrm{day}=$ $56 \mathrm{ml} / \mathrm{kg} /$ day $=$ GUR $4 \mathrm{mg} / \mathrm{kg} / \mathrm{min}$

Expressed breast milk (EBM) volume, if regular

- Deduct from the $10 \%$ dextrose drip if baby is maintaining blood sugar $>45 \mathrm{mg} / \mathrm{dl}$

- Deduct from Vaminolact if blood sugar is dropping below $45 \mathrm{mg} / \mathrm{dl}$

Day 3

- If mother is getting EBM $>50 \%$ volume of the total fluid, PN can be stopped and baby can be on a plain $10 \%$ dextrose drip

- If the enteral feeds are $>75 \%$ of the total fluid volume - the IV fluids can be stopped.

Total fluid volume $=100-120 \mathrm{ml} / \mathrm{kg} /$ day

$50 \%$ volume $=50-60 \mathrm{ml} / \mathrm{kg} / \mathrm{day}=\mathrm{EBM} 4-5 \mathrm{ml} 2$ hourly - stop PN

$75 \%$ volume $=75 \mathrm{ml} / \mathrm{kg} /$ day $=\mathrm{EBM} 6 \mathrm{ml} 2$ hourly

- stop IV fluids

- If the EBM volume is $<50 \% \mathrm{PN}$ needs to be continued, and electrolytes should be added.

Total fluids $=120 \mathrm{ml} / \mathrm{kg} /$ day $=120 \mathrm{ml} /$ day

Protein $2.5 \mathrm{~g} / \mathrm{kg} /$ day $=$ Vaminolact $43 \mathrm{ml} / \mathrm{kg} /$ day $=$ $43 \mathrm{ml} /$ day

Lipid $2 \mathrm{~g} / \mathrm{kg} /$ day $=$ Lipofundin $10 \%-20 \mathrm{ml} / \mathrm{kg} /$ day

$=20 \mathrm{ml} /$ day

Add electrolytes on Day 3

$3 \% \mathrm{NaCl} 4 \mathrm{mmol} / \mathrm{kg} /$ day $=8 \mathrm{ml} / \mathrm{kg} /$ day $=8 \mathrm{ml} /$ day

$\mathrm{KCL} 2 \mathrm{mmol} / \mathrm{kg} /$ day $=1 \mathrm{ml} / \mathrm{kg} /$ day $=1 \mathrm{ml} /$ day

Rest as $10 \%$ dextrose $=48 \mathrm{ml} /$ day $=48 \mathrm{ml} / \mathrm{kg} /$ day GUR $<4 \mathrm{mg} / \mathrm{kg} / \mathrm{min}$ *

Regular EBM also needs to be deducted

*In this instance amount of dextrose provided is below minimum recommended, therefore we would need to reduce protein and lipid volumes (go back 1 step - protein $2 \mathrm{~g} / \mathrm{kg} /$ day and lipid $1 \mathrm{~g} / \mathrm{kg}$ /day) to accommodate more dextrose / EBM to maintain the minimum GUR.

\section{Enteral Nutrition}

Breast milk is the preferred enteral feed even for preterm babies!

$\mathrm{BM}$ is the best form of enteral feeding, even for preterm babies ${ }^{21}$. BM overcomes challenges posed to preterms by antibiotic use, caesarean section and multiple handling via immune modulation. It helps to attain full feeds quickly by causing less feed intolerance via mechanical and biochemical priming of the gut. Babies who are fed $\mathrm{BM}>50$ $\mathrm{ml} / \mathrm{kg} /$ day have less incidence of necrotising enterocolitis (NEC) as well as late onset sepsis. There is a $5 \%$ decrease in the rate of hospital admission due to respiratory illness in the first year of life for each $10 \mathrm{ml} / \mathrm{kg} /$ day of BM. Babies fed $\mathrm{BM}$ also have lesser incidence of retinopathy of prematurity (ROP) as well as metabolic syndrome $^{22,23}$. A study done by Lucas et al in 1992 found that preterm infants fed BM in their early days had a 8.3 point advantage in intelligence quotient (IQ) measured by the Wechsler Intelligence Scale for Children (Revised) (WISCR) at 7-8 years of age over those fed with artificial milk after controlling for social class, maternal education, birth weight, gestational age, birth rank and maternal age ${ }^{24}$. Breast feeding independently improves the neurodevelopmental outcome irrespective of the poorer weight gain - this has been named the breast feeding paradox ${ }^{25}$.

\section{When should we start breast milk?}

$\mathrm{BM}$ should be given to baby as soon as the baby is stabilised as there is no evidence that delayed introduction of progressive enteral feeds prevents NEC in VLBW infants ${ }^{26,27}$. A study done in DSHW in $2012 / 2013$ revealed that all babies $<34$ weeks were started on enteral feeds on Day 1 of life ${ }^{20}$.

\section{Rate of advancement of feeds}

Feeds should be advanced as they become available as slowly advancing milk feeds does not reduce the risk of NEC in VLBW infants ${ }^{28}$. A study done in DSHW in 2012/2013 revealed that all babies $<34$ weeks in whom feeds were started on Day 1 and reached full feeds on Day 3 showed better weight gain, less culture positive sepsis, less duration of IV therapy without any increase in mortality or NEC compared to babies who were started on feeds on Day 3 and advanced to full feeds on Day $9^{29}$.

\section{Breast milk meets the increased protein and energy requirement for most preterm babies} Preterm infants require large amounts of protein and energy to achieve normal growth. The protein in $\mathrm{BM}$ is predominantly whey, which is easily digested and of higher quality than that in artificial 
milks. Preterm milk is more nutrient dense, has higher amount of protein, fat, energy, $\mathrm{Na}$, chloride, $\mathrm{Ca}, \mathrm{K}$, iron and $\mathrm{Mg}$. The BM of the mother whose baby is born at 28 weeks gestation is more energy dense than that of a mother whose baby is born at 36 weeks gestation. Over time ( 3 weeks after birth), protein content decreases and the fat, lactose and energy content increases due to slow closure of the tight junctions between lactocytes, thereby giving more energy per $\mathrm{ml}$ of BM as the baby get older ${ }^{30}$. Energy and fluid requirements are met by providing an adequate volume of BM ranging from $160 \mathrm{ml} / \mathrm{kg} /$ day to $180 \mathrm{ml} / \mathrm{kg} /$ day $(0.67 \mathrm{kcal} / \mathrm{ml})$. Milk from a fully emptied breast is likely to provide an adequate energy density due to the collection of high fat hind milk. Babies fed hind milk have shown a higher weight gain compared to those fed composite milk ${ }^{31}$. EE is significantly less when preterm infants are fed with BM rather than artificial $\mathrm{milk}^{32}$. Additional $\mathrm{Ca}, \mathrm{P}$, vitamin $\mathrm{D}$, multivitamin and iron are supplemented when the baby is on full feeds.

\section{The place for breast milk fortifiers}

The developed world uses fortifiers almost universally, as they perceive that BM alone does not supply enough protein, $\mathrm{Ca}$ and energy to satisfy the needs of the preterm baby. But do we, a country with very good breast feeding rates need to ape the West? Although fortifiers are called "breast milk / human milk fortifiers" almost all are derived from cow's milk. Fortifiers may cause short term benefit in terms of better anthropometry in the immediate period. There is no clear effect on bone mineral content. There is no evidence that these short term benefits lead to any demonstrable long term benefits on growth, bone mineral content and neurodevelopmental outcome ${ }^{33}$.

Following are risks associated with the use of cow's milk based human milk fortifiers:

- Increases incidence of $\mathrm{NEC}^{34}$

- Increases osmolarity causing gastrooesophageal reflux (GOR)
- $\quad$ Increases risk of infection ${ }^{34}$ with Enterobacter sakazakii ${ }^{35}$, Escherichia coli, Clostridium difficile and Shigella sonnei

- Increases risk of contamination of the milk

- Introduces cow's milk protein to infant increasing risk of allergy, and diabetes mellitus

BM fortifiers should be reserved for babies who are not achieving a weight gain of 15-20 g/day while on adequate volume of BM (160-180 ml/ $\mathrm{kg} /$ day), a very rare occurrence unless the baby has a medical complication. Only $2 / 60$ babies needed fortifier in 2012/13, at DSHW, one baby who was awaiting surgery for a patent ductus arteriosus (PDA) and was on restricted fluid volumes and the other with chronic lung disease who was on nasal continuous positive airway pressure (CPAP) for 2 months $^{20}$.

\section{The place of donor milk}

Donor milk is mostly collected from mothers of healthy term babies expressing after a breast feed, less often from mothers of babies who have died or rarely in mothers whose babies are in the neonatal unit and have expressed milk in excess of requirements ${ }^{19}$. Most countries take measures to minimise the transmission of virus and bacteria. In UK the donors are serologically tested for HIV, Hep B/C, HTLV 1 and 2 and syphilis following which the milk undergoes Holter pasteurisation ${ }^{23}$.

Why donor milk is not as good as mothers' milk ${ }^{23}$ :

- Donor milk obtained from term babies is less nutrient rich (especially protein)

- Pasteurisation reduces the immune factors

Donor milk might be beneficial in reducing risk of NEC and improving long term outcomes like cognition, bone mineral content and cardiovascular health compared to formula but should not be used the same way as maternal $\mathrm{BM}^{23}$.

Table 5: A comparison between maternal milk, donor milk and formula milk ${ }^{22}$

\begin{tabular}{|l|c|c|c|}
\hline & Maternal milk & Donor milk & Formula \\
\hline Growth & ++ & + & +++ \\
\hline NEC & & ++ & ++++ \\
\hline ROP & & ++ & ++ \\
\hline Late sepsis & ++ & ++ \\
\hline Length of hospital stay & & ++ & ++ \\
\hline Mortality & & ++ & ++ \\
\hline
\end{tabular}

Following steps would help in the successful establishment of breast feeding in preterm babies $^{36}$ :

\section{Initiation of breast feeding}

- The neonatologist/paediatrician and senior nurse should unequivocally tell the mothers that their BM is the best food for their baby 
- Empower, educate and train staff in maternity wards, labour rooms, maternal intensive care unit to express milk from mother as early as possible within the first 6 hours after birth

- Mother should be given realistic expectations regarding the initial milk volume because the amount produced can be as little as half a drop of colostrum at each milk expression in the first 24 to 48 hours postpartum

- Encourage mother to visit the neonatal unit as soon as possible and touch / talk / sing / read to baby (this can be done for all babies in neonatal intensive care unit (NICU), irrespective of their medical condition)

- Early implementation of kangaroo mother care (KMC) for even the smallest babies (KMC is given to all babies receiving non invasive ventilation at DSHW)

- Encourage and assist the mother into KMC as often, and for as long, as possible.

- Monitor milk volumes closely to prevent and treat low supply

\section{Sustaining breast feeding}

- Continue to express BM and empty the breast at least 8 times a day

- Emphasize the need for complete emptying of the breast

- Always show interest in daily amounts expressed

- Observe the mother's expressing or pumping technique from time to time

- Involve mother in the feeding plan

- Give positive feedback, frequently!

- Stress the importance of BM "Your BM is great for your baby because..." and incorporate it into your conversations every day.

- Encourage and assist the mother into KMC as often, and for as long, as possible

- Discuss encouraging her to let baby nuzzle and suckle at her recently-emptied / expressed breast if baby is not yet able to breastfeed.

\section{Lactation insufficiency}

By Day 10 after birth, the goal is for the mother to be expressing more than $750 \mathrm{ml}$ of milk per day. Ensure all of the following are a part of care if the milk volumes are less than expected:

- Breast massage and hand expressing

- $\quad$ Skin-to-skin contact with baby

- Pumping beside baby

- Suckling on the empty breast

- Professional and peer support

\section{Transition from Tube to Breast}

\section{Maturation of feeding related functions}

There is a chronological order in which the newborn reflexes and responses mature.
Development of nutritive suck and swallow ${ }^{37}$ :

- 9th week post-conception - moves mouth and lower face

- 11th week - swallow

- 18 - 24 weeks - non-nutritive suck

- 32- 35 weeks - nutritive suck and swallow

These times have been set following observation of preterm babies in standard incubator care. KMC is demonstrating that babies advance through these milestones more quickly than indicated above and have demonstrated co-ordinated suck and swallow in babies as young as 28 to 30 weeks. Therefore, it is recommended to put a baby to the breast once it shows cardio-respiratory stability rather than based on the maturity. The muscles and ligaments of the face and mouth as well as the facial fat and sucking pads which play an important role in postural stability during feeding are poorly developed in preterm babies. Hold preterm babies so they are well supported and in a flexed position as they lack postural control in the cervical area which causes difficulty in providing adequate stability for head and neck motions during breastfeeding.

\section{Assessing maturational readiness ${ }^{38}$}

This assessment should be done as the baby suckles the empty breast during $\mathrm{KMC}$ following recent milk expression.

Assessing readiness to breast feed:

- Evaluating for spontaneous initiation of suck

- Differentiating between non-nutritive (several sucks: 1 breath) and nutritive sucking (1 suck: 1 breath with a pause after 3 to 4 deep sucks)

- Observing tongue movement - whether it is centrally troughed, if the tip extends beyond gum margin, if it drops with onset of negative pressure

- Coordination of suck/swallow/breathe

Most preterm infants have a 'disorganised' suck with inconsistent, arrhythmic tongue and jaw movement along with a transitional suck pattern (5 -7 suck, swallows per breath) $)^{39,40}$.

Oral Experience ${ }^{41}$

Suctioning, intubation and passage of feeding tubes (oro- or naso-) are unpleasant procedures done via mouth which is the most sensitive organ in a newborn. This causes baby to develop oral aversion, a significant problem when trying to commence oral feeding. Therefore, it is of paramount importance that we initiate pleasant oral experiences alongside the unpleasant but necessary traumatic procedures:

- Minimal volumes (i.e. $<1 \mathrm{ml}$ ) of BM could be trickled into baby's mouth during tube feeds, when unable to be at the mother's breast. 
- Allowing licks and smells at the breast as soon as baby is extubated is important as the preterm baby has missed out on many weeks of practising in utero to suck and swallow. This is easiest to achieve when in KMC. Baby should be allowed to latch and 'practice suck' on a recently expressed or pumped breast until adequate sucking maturation is evident.

- Allowing the baby to suck on a clean finger, if the mother is not available for $\mathrm{KMC}$ - pacifier use is not recommended.

Tube to breast alone or tube to cup and breast Energy expended by baby increases as baby becomes more and more involved in feed. Tube feeds require least amount of energy versus direct breast feeds, the highest amount of energy. Growth will depend on difference between the energy gained via BM and energy expenditure. Therefore growth and weight gain will be faster if less energy expending feeding methods are employed. Babies can be transitioned from the tube to the breast directly or from tube to both simultaneous cup feeds and breast feeds. This can be done by giving a few minutes on the breast followed by the tube, increasing the time on the breast as the baby has a more mature suckling pattern.

\section{Tube to cup and breast}

Baby should be put on to the empty breast to suckle during $\mathrm{KMC}$, if he is cardiovascularly stable (even babies who are ventilated). It is important to start as early as possible in order for baby to associate breast feeding as a positive oral experience. Cup feeds can be started if baby is stable in addition to time on the empty breast. Initially the well trained health care staff will give the cup feed and assess the readiness of the baby to take the cup feed. If the baby is taking a long time to feed via the cup it means that the baby is not ready for full cup feeds; in this instance cup feed for about $20 \mathrm{~min}$, give the rest via nasogastric (NG) tube. When baby matures and finishes the cup with ease within 20-30 minutes tube feeds can be completely stopped and the staff can train the mother on cup feeds in addition to breast feeds. Initially the breast feeds are given for a short time (10- $15 \mathrm{~min})$, and then followed by the cup feed which should easily finish within 20-30 min. It is important to restrict the time at the breast as baby gets tired if feeding attempts are carried out for a long time. As the baby matures and suckling improves the baby will start taking more milk from the breast with a mature nutritive suckling pattern and will take less from the cup. Thus the baby will wean off the cup gradually get on to complete direct breast feeds with time. Using both cup and breast feeds enable the baby to be weaned off sooner from the tube as energy expenditure will be less with cup and breast compared to breast alone.
Bottles or pacifiers should never be used as it confuses the baby with regard to the technique of sucking from the breast and sucking from the teat.

Energy expenditure was not found to be higher in breast feeding compared to bottle feeding ${ }^{42}$

Following issues need to be addressed if there is not enough weight gain $(<15 \mathrm{~g} / \mathrm{day})^{2}$ on $\mathrm{BM}$ :

- Is there a medical complication?

- Adequate volumes of breast milk?

- Is hind milk being given?

- Express into 2-3 cups - give last cup first

- Is the baby getting too tired?

- Shorten the duration of the breast feed $10-15 \mathrm{~min}$

- Ensure that cup feeds do not take more than $30 \mathrm{~min}$

If the milk volume is decreasing - it is due to poor management!

The following measures would be helpful to increase the milk volume:

- Build confidence in the mother - $\uparrow$ oxytocin

- $\quad$ Ensure that breast is completely emptied 2 hourly - $\uparrow$ prolactin / $\downarrow$ inhibitor

- Ensure that expression occurs $2 \mathrm{hrly}$ at night as well - $\uparrow$ prolactin - DO NOT REST

MOTHER FROM 12am - 6am

- $\quad$ Give / increase skin to skin contact $-\uparrow$ oxytocin

- $\quad$ Get mother to touch/talk to baby $-\uparrow$ bonding $\uparrow$ oxytocin

- $\quad$ Facilitate baby to suckle on the empty breast $\uparrow$ oxytocin $>$ prolactin

Prevention of osteopenia of prematurity by Ca, $P$ and vitamin D supplementation ${ }^{43}$

Osteopenia of prematurity is commoner in babies who are $<1500 \mathrm{~g},<28$ weeks, affected with chronic lung disease (CLD) and those who are immobile. $\mathrm{Ca} / \mathrm{P}$ ratio in human milk is the same as the recommended ratio by the American Association of Paediatricians (AAP). Baby should be screened via serum $\mathrm{Ca}, \mathrm{P}$ and ALP levels starting at 6 weeks postnatal age and continued at 2 weekly intervals. An ALP $>900$ and $P<1.8 \mathrm{mmol} / \mathrm{l}$ has $100 \%$ sensitivity but only $70 \%$ specificity. Prevention is by supplementing baby with $\mathrm{Ca} 200 \mathrm{mg} / \mathrm{kg} /$ day, $\mathrm{P}$ $90 \mathrm{mg} / \mathrm{kg} /$ day, vitamin D 200-400 IU till 3.5-4 kg along with early commencement of feeds. A baby with osteopenia, rickets or fractures has to be treated until normalisation of the ALP or for 6 months postnatally. In the Sri Lankan setting, $5 \mathrm{ml}$ of Ostocalcium which provides $81 \mathrm{mg} \mathrm{Ca}, 42 \mathrm{mg} \mathrm{P}$ and Vitamin D 400 IU can be used at 8-10 $\mathrm{ml} / \mathrm{kg} /$ day to achieve the recommended supplementation doses. This should be commenced 
as soon as the baby is on full enteral feeds. A study on the success of breast feeding in $<34$ week preterm babies done at DSHW in 2012/13 did not find any preterm baby to have osteopenia, rickets or fractures ${ }^{20}$.

Prevention of anaemia of prematurity by iron supplementation ${ }^{43}$

Decreased haemoglobin is a late finding and the brain may already be damaged by this time. Therefore iron supplements have to be started early before the baby is symptomatic. It is safe to start iron supplements with a minimal enteral feed of $100 \mathrm{ml} / \mathrm{kg} /$ day. The prophylactic dose would be 2 $\mathrm{mg} / \mathrm{kg} /$ day till 6-12 months of corrected gestational age whereas the treatment dose if already anaemic is $6 \mathrm{mg} / \mathrm{kg} /$ day. Be aware that different preparations have different concentrations of elemental iron (Orofer drops $1 \mathrm{ml}=50 \mathrm{mg}$, Orofer syrup $5 \mathrm{ml}=50 \mathrm{mg}$, Iberol Drops $1 \mathrm{ml}=25 \mathrm{mg}$ ). It is also important to remember to be very sparse with blood investigations for small preterm babies as several blood investigations may remove enough blood volume to warrant red cell transfusion.

\section{Zinc and vitamin supplementation}

Many ex-preterm babies have subtle zinc deficiency which may benefit from extra zinc. Current recommended intakes for enterally fed babies are $500-1000 \mu \mathrm{g} / \mathrm{kg} / \mathrm{day}^{\mathbf{4 3}}$. As in all humans the preterm baby has a limited reserve of water soluble vitamins and needs a constant supply to avoid deficiency. The use of large doses of vitamin E for prevention of ROP or bronchopulmonary dysplasia is not recommended.

Table 6: Vitamin requirement in preterm babies compared to the available local preparations

\begin{tabular}{|c|c|c|c|c|}
\hline & $\begin{array}{l}\text { Recommended } \\
\text { dietary intake }\end{array}$ & Breast milk & Grovit $0.6 \mathrm{ml}$ & Zincovit 1ml \\
\hline $\begin{array}{c}\text { Vitamin } \mathrm{A}^{44} \\
<1 \mathrm{~kg} \\
1-1.75 \mathrm{~kg} \\
1.75-2.5 \mathrm{~kg} \\
>2.5 \mathrm{~kg}\end{array}$ & $\begin{array}{c}1500 \mathrm{IU} / \mathrm{kg} / \text { day } \\
700-1500 \mathrm{IU} / \mathrm{kg} / \text { day } \\
700 \mathrm{IU} / \mathrm{kg} / \text { day } \\
333 \mathrm{IU} / \mathrm{kg} / \text { day }\end{array}$ & $\begin{array}{c}450 \mathrm{IU} / \mathrm{kg} / \text { day }(150 \\
\mathrm{ml} / \mathrm{kg} / \text { day })\end{array}$ & $3000 \mathrm{IU}$ & $2500 \mathrm{IU}$ \\
\hline Vitamin $\mathrm{E}^{45}$ & $\begin{array}{c}5 \mathrm{IU} / \text { day + breast } \\
\text { milk }\end{array}$ & Good source & $5 \mathrm{mg}$ & $2.5 \mathrm{IU}$ \\
\hline Vitamin $\mathrm{D}^{46}$ & $200-400 \mathrm{IU}$ & & $400 \mathrm{IU}$ & 200IU \\
\hline Vitamin $\mathrm{C}^{47}$ & $20 \mathrm{mg} / 100 \mathrm{kcal}$ & $8 \mathrm{mg} / 100 \mathrm{kcal}$ & $40 \mathrm{mg}$ & $40 \mathrm{mg}$ \\
\hline Vitamin $B 1^{47}$ & $300 \mu \mathrm{g} / 100 \mathrm{kcal}$ & $29 \mu \mathrm{g} / 100 \mathrm{kcal}$ & $2 \mathrm{mg}$ & $1 \mathrm{mg}$ \\
\hline Vitamin B2 $^{47}$ & $300 \mu \mathrm{g} / 100 \mathrm{kcal}$ & $60 \mu \mathrm{g} / 100 \mathrm{kcal}$ & $1 \mathrm{mg}$ & $1 \mathrm{mg}$ \\
\hline Vitamin $\mathrm{B} 6^{47}$ & $150 \mu \mathrm{g} / 100 \mathrm{kcal}$ & $28 \mu \mathrm{g} / 100 \mathrm{kcal}$ & $1 \mathrm{mg}$ & $0.5 \mathrm{mg}$ \\
\hline $\operatorname{Niacin}^{47}$ & $4 \mathrm{mg} / 100 \mathrm{kcal}$ & $210 \mu \mathrm{g} / 100 \mathrm{kcal}$ & $10 \mathrm{mg}$ & $10 \mathrm{mg}$ \\
\hline Biotin $^{47}$ & $5 \mu \mathrm{g} / 100 \mathrm{kcal}$ & $0.56 \mu \mathrm{g} / 100 \mathrm{kcal}$ & & \\
\hline Pantothenic acid ${ }^{47}$ & $1.4 \mu \mathrm{g} / 100 \mathrm{kcal}$ & $250 \mu \mathrm{g} / 100 \mathrm{kcal}$ & & \\
\hline Zinc $^{43}$ & $500-1000 \mu \mathrm{g} / \mathrm{kg} /$ day & & & $13.3 \mathrm{mg}$ \\
\hline Folic acid 48 & $50 \mu \mathrm{g} /$ day & $50 \mu \mathrm{g} / \mathrm{L}$ & & \\
\hline Vitamin B12 48 & & Adequate supply & & \\
\hline
\end{tabular}

Vitamin K supplementation in preterm babies A preventive vitamin $\mathrm{K}$ injection is recommended at/soon after birth as BM has low vitamin $\mathrm{K}$ content $^{49}$.

Babies $1 \mathrm{~kg}$ or less $-0.3 \mathrm{mg} / \mathrm{kg} \mathrm{IV}$

Babies $>1 \mathrm{~kg}-1 \mathrm{mg}$ IM

On Day 7 of life if babies are fully breast fed at 150 $\mathrm{ml} / \mathrm{kg} /$ day or more give oral vitamin $\mathrm{K} 0.4 \mathrm{mg} / \mathrm{kg}$ weekly until 6 weeks of age $e^{50,51}$.

\section{Catch up growth in preterms}

Growth velocity in the human is higher at 25 or 30 weeks compared to that at 40 weeks and if poor growth occurs at this time due to inadequate nutrition, adequate catch up growth may be impossible whatever the amount or quality of nutrient intake ${ }^{2}$. Intrauterine growth curves are being used as the growth standard for preterm babies as they are expected to grow similar to the fetus. However, these intrauterine growth curves have been constructed from small amount of data from preterms with unsure gestation. Also the extra-uterine environment and extra-uterine nutrition are completely different from the intrauterine environment. So a new wave of thought is emerging as to whether it is physiological for these babies to follow the intrauterine growth curves? ${ }^{52}$

Inadequate catch up growth has been defined as being less than the $10^{\text {th }}$ percentile for weight, length or occipito-frontal circumference (OFC). Failure of catch up growth has been seen to rise with decreasing birth weight. Further, there are issues as to when catch up growth is completed. But does catch growth really matter? A recent study on 179 
$<28$ weekers from Australia in 1991-1995 revealed that the catch up growth was not associated with 8 year outcomes. This study revealed that the weight at any age was unrelated to any outcome although a small OFC at 2 and 8 years were associated with poor neurodevelopmental outcome ${ }^{53}$. Infants who show catch up growth carry a higher proportion of body fat, particularly abdominal fat as children and adults. There are many studies that link rapid catch up growth with subsequent risks of obesity ${ }^{54-60}$. This association between catch up growth and chronic disease in adulthood has led to the idea that postnatal catch up growth should be restricted to prevent a later adverse metabolic profile ${ }^{61,62}$. Nutritional and metabolic exposure during the critical period of early human development is known to have a long term programming effect on adult health. It is also thought that obesity and metabolic syndrome may have developmental origins. Babies who show rapid catch up growth are at increased risk of obesity, heart disease and chronic kidney disease ${ }^{63-64}$.

\section{Points to remember:}

- Encourage and support the mother and express breast milk in the first 6 hours after birth

- Start EBM and PN via peripheral route as soon as possible on Day 1

- Advance feeds as tolerated by the baby and remove IV lines as soon as possible

- Supplement with calcium phosphate, multivitamins, zinc and iron when on full feeds

- Aim for modest growth of $15 \mathrm{~g} / \mathrm{kg} /$ day

- Catch up growth can be harmful

\section{References}

1. Velaphi S. Review: Nutritional requirements and parenteral nutrition in preterm infants. South African Journal of Clinical Nutrition 2011;24(3):S27-S31

2. Putet G. Energy. In: Tsang RC, Lucas A, Uauy $\mathrm{R}$, Zlotkin S, editors. Nutritional Needs of the Preterm Infant: Scientific Basis and Practical Guidelines. New York: Williams \& Wilkins; 1993: p. 15-28.

3. Slunchiva B. Strategies for nutrition of the preterm infant with low and very low birth weight Akush Ginekol (Sofiia) 2010; 49(2):339.

4. American Academy of Pediatrics Committee on Nutrition: Nutritional needs of low-birth weight infants. Pediatrics 1985; 75(5):976-86.

5. De Curtis M, Rigo J. The nutrition of preterm infants. Early Human Development 2012; 88 (Suppl. 1): S5-7. http://dx.doi.org/10.1016/j.earlhumdev.2011.1 2.020

6. Early parenteral nutrition and growth outcomes in preterm infants: a systematic review and meta-analysis. American Journal of Clinical Nutrition 2013; 97(4): 816-26.

http://dx.doi.org/10.3945/ajcn.112.042028

7. Hulzebos CV, Sauer PJJ. Energy requirements. Seminars in Fetal and Neonatal Medicine 2007; 12(1): 2-10.

http://dx.doi.org/10.1016/j.siny.2006.10.008

8. Lucas A, Morley R, Cole TJ. Adverse neurodevelopmental outcome of moderate neonatal hypoglycaemia British Medical Journal 1988; 297:1304-8. http://dx.doi.org/10.1136/bmj.297.6659.1304

9. Clandinin MT, Chappell JE, Leong S, et al. Intrauterine fatty acid accretion rates in human brain: implications for fatty acid requirements. Early Human Development 1980; 4:121-9. http://dx.doi.org/10.1016/03783782(80)90016$\mathrm{X}$

10. Carlson SE, Werkman SH, Rhodes PG, et al. Visual acuity development in healthy preterm infants: effect of marine oil supplementation. American Journal of Clinical Nutrition 1993; 58:35-42.

11. Pondexter BB, Langer JC, Dusick AM, et al. National Institute of Child Health and Human Development Neonatal Research Network. Early provision of parenteral amino acids in extremely low birth weight infants: relation to growth and neurodevelopmental outcome. Journal of Pediatrics 2006; 148: 300-5. http://dx.doi.org/10.1016/j.jpeds.2005.10.038

12. Isaacs EB, Gadian DG, Sabatini S, et al. The effect of early human diet on caudate volumes and IQ. Pediatric Research 2008; 63:308-14. http://dx.doi.org/10.1203/PDR.0b013e318163a 271

13. Embleton ND. Optimal protein and energy intakes in preterm infants Early Human Development 2007; 83:831-7. http://dx.doi.org/10.1016/j.earlhumdev.2007.1 0.001

14. Hay WW Jr. Strategies for feeding the preterm infant Neonatology 2008; 94:245-54. http://dx.doi.org/10.1159/000151643

15. Hay WW, Thureen P. Protein for preterm infants: How much is needed? How much is 
enough? How much is too much? Pediatrics \& Neonatology 2010; 51:198-207. http://dx.doi.org/10.1016/S18759572(10)6003 9-3

16. Costarino AT Jr, Baumgart S. Water as Nutrition. In: Tsang RC, Lucas A, Uauy R, Zlotkin S, editors. Nutritional Needs of the Preterm Infant: Scientific Basis and Practical Guidelines. New York: Williams \& Wilkins; 1993: p. 1-14.

17. Rigo J, Senterre T. Intrauterine-like growth rates can be achieved with premixed parenteral nutrition solution in preterm infants. Journal of Nutrition 2013; 143 (12 Suppl): 2066S-2070S http://dx.doi.org/10.3945/jn.113.177006

18. Payne-James JJ, Khawaja HT. First choice for parenteral nutrition: the peripheral route. Journal of Parenteral and Enteral Nutrition 1993; 17(5): 468-78. http://dx.doi.org/10.1177/01486071930170054 68

19. Lucas MN, Weerasekera M. A prospective study of ventilated neonates in a tertiary care hospital in Sri Lanka compared to retrospective data from the same unit. Sri Lanka Journal of Child Health, 2013; 42(1): 10-19 http://dx.doi.org/10.4038/sljch.v42i1.5289

20. Lucas MN, Samarakkody SN, Chathurangi DML. Success of breast feeding among preterms $\leq 34$ weeks in a neonatal unit in Sri Lanka. Proceedings of the Sri Lanka College of Paediatricians $16^{\text {th }}$ Annual Scientific Congress, August 2013; 4(2): 56.

21. Policy Statement of the American Academy of Pediatrics. Breast feeding and use of human Milk. Pediatrics 2005; 115(2) 496 - 506. http://dx.doi.org/10.1542/peds.2004-2491

22. Underwood MA. Review. Human milk for the premature infant. Paediatric Clinics of North America 2013; 60(1): 189-207. http://dx.doi.org/10.1016/j.pcl.2012.09.008

23. Review. Human milk for preterm infants: why, what, when and how? Archives of Disease in Childhood Fetal and Neonatal Edition 2013; 98(6): F559-F62.

http://dx.doi.org/10.1136/archdischild-2012303582

24. Lucas A, Morley R, Cole TJ, Lister G, LessonPayne C. Breast milk and subsequent intelligence quotient in children born preterm. Lancet 1992; 339:261-4. http://dx.doi.org/10.1016/01406736(92)913297

25. Roze J-C, Darmaun D, Boquien C-Y, Flamant C, Picaud J-C, Savagner C, et al. The apparent breastfeeding paradox in very preterm infants: relationship between breastfeeding, early weight gain and neurodevelopment based on results from 2 cohorts, EPIPAGE and LIFT. BMJ Open 2012; 2(2):e000834

http://dx.doi.org/10.1136/bmjopen-2012 000834

26. Morgan J, Bombell S. McGuire W. Early trophic feeding versus enteral fasting for very preterm or low birth weight infants. Cochrane Database of Systematic Reviews 2013. Issue 3. Art. No.: CD000504.

http://dx.doi.org/10.1002/14651858.CD000504 .pub4

27. Morgan J, Young L, McGuire W. Delayed introduction of progressive enteral feeds to prevent necrotising enterocolitis in very low birth weight infants. Cochrane Database of Systematic Reviews 2013. May 31; 5: CD001970.

28. Morgan J, Young L, McGuire W. Slow advancement of enteral feed volumes to prevent necrotising enterocolitis in very low birth weight infants. Cochrane Database of Systematic Reviews 2013. Issue 3. Art. No.: CD001241.

http://dx.doi.org/10.1002/14651858.CD000504 .pub4

29. Lucas MN, Bandara KMKC, Samarakkody SN, Chathurangi DML. Early initiation and rapid progression of expressed breast milk in preterm babies: Is it safe? Congress Proceedings of the $13^{\text {th }}$ Scientific Meeting of the Commonwealth Association of Paediatric Gastroenterology and Nutrition, December 2013: p21.

30. Paul VK, Singh M, Srivastava LM, Arora NK, Deorari AK. Macronutrient and energy content of breast milk of mothers delivering prematurely. Indian Journal of Pediatrics 1997; 64(3) 379-82. http://dx.doi.org/10.1007/BF02845209

31. Ogechi AA, William O, Fidelia BT. Hindmilk and weight gain in preterm very low birth weight infants. Pediatr Int. 2007; 49(2): 15660.

http://dx.doi.org/10.1111/j.1442200X.2007.02 336. $x$ 
32. Lubetzky R, Vaisman N, Mimouni FB, Dollberg S. Energy expenditure in human milk versus formula-fed preterm infants. The Journal of Pediatrics 2003; 143(6): 750 -3. http://dx.doi.org/10.1067/S00223476(03)0053 $2-8$

33. Kuschel CA, Harding JE. Multi component fortified human milk for promoting growth in preterm infants. Cochrane Neonatal Review, January 2004. Available from: http://www.nichd.nih.gov/cochrane_data/kusch elc_01/kuschelc_01.html

34. Lucas A, Fewtrell MS, Morley R, et al. Randomized outcome trial of human milk fortification and developmental outcome in preterm infants. American Journal of Clinical Nutrition 1996 ; 64: 142-51

35. Bowen AB, Braden CR. Invasive Enterobacter saksazakii disease in infants. Emerging Infectious Diseases August 2006; 12(8). Available from:

http://wwwnc.cdc.gov/eid/article/12/8/051509 article.htm http://dx.doi.org/10.3201/eid1208.051509

36. Jones E. Principles to promote the initiation and establishment of lactation in the mother of a preterm or sick infant. Journal of Perinatal and Neonatal Nursing 2003; 17 (1): 50-64.

37. Delaney AL, Arverdson JC. Development of swallowing and feeding: prenatal through first year of life. Dev Disabil Res Rev. 2008; 14: 105-17.

http://dx.doi.org/10.1002/ddrr.16

38. McBride MC, Danner SC. Sucking disorders in neurologically impaired infants: assessment and facilitation of breastfeeding. Clinical Perinatol. 1987; 14: 103-9.

39. Bowen-Jones A, Thompson C, Drewett RF. Milk flow and sucking rates during breastfeeding. Developmental Medicine and Child Neurology 1982; 24: 626-33.

http://dx.doi.org/10.1111/j.14698749.1982.tb1 3673. $\mathrm{x}$

40. Dreier T, Wolff PH. The serial organization of sucking in the young infant. Pediatrics 1968; 42(6): 943-56.

41. Healow LK, Hugh RS. Oral aversion in the breast fed neonate. Breastfeeding Abstracts. 2000: 20(1); 3-4.
42. Berger I, Weintraub V, Dollberg S, Kopolovitz R, Mandel D. Energy expenditure for breast feeding and bottle feeding preterm infants. Pediatrics 2009; 124(6): e1149-e1152. http://dx.doi.org/10.1542/peds.2009-0165

43. Shah MD, Shah SR. Nutrient deficiencies in the premature infant. Pediatric Clinics of North America 2009; 56 (5): 1069-83. http://dx.doi.org/10.1016/j.pcl.2009.08.001

44. Shenai JP. Vitamin A. In: Tsang RC, Lucas A, Uauy R, Zlotkin S, editors. Nutritional Needs of the Preterm Infant: Scientific Basis and Practical Guidelines. New York: Williams \& Wilkins; 1993: p. 87-100.

45. Gross SJ. Vitamin E. In: Tsang RC, Lucas A, Uauy R, Zlotkin S, editors. Nutritional Needs of the Preterm Infant: Scientific Basis and Practical Guidelines. New York: Williams \& Wilkins; 1993: p. 101-9.

46. Koo WWK, Tsang RC. Calcium, Magnesium, Phosphorus and Vitamin D. In: Tsang RC, Lucas A, Uauy R, Zlotkin S, editors. Nutritional Needs of the Preterm Infant: Scientific Basis and Practical Guidelines. New York: Williams \& Wilkins; 1993: p. 135-55.

47. Greene HL, Smidt LJ. Water-soluble Vitamins. In: Tsang RC, Lucas A, Uauy R, Zlotkin S, editors. Nutritional Needs of the Preterm Infant: Scientific Basis and Practical Guidelines. New York: Williams \& Wilkins; 1993: p. 121-133.

48. Ehrenkranz RA. Iron, Folic Acid and Vitamin B12. In: Tsang RC, Lucas A, Uauy R, Zlotkin $\mathrm{S}$, editors. Nutritional Needs of the Preterm Infant: Scientific Basis and Practical Guidelines. New York: Williams \& Wilkins; 1993: p. 177-194.

49. Greer FR. Vitamin K. In: Tsang RC, Lucas A, Uauy R, Zlotkin S, editors. Nutritional Needs of the Preterm Infant: Scientific Basis and Practical Guidelines. New York: Williams \& Wilkins; 1993: p. 111-9.

50. Clarke P, Mitchell S, Wynn R, et al. Vitamin K prophylaxis for preterm infants: A randomized controlled trial of 3 regimens. Pediatrics 2006; 118(6): e1657-e1666.

51. Vitamin K1 - Guidelines for administration. QCCH Neonatal Formulary 2008. $9^{\text {th }}$ Edition; p. 77-83. 
52. Saeur PJ. Can extra-uterine growth approximate intrauterine growth? Should it? American Journal of Clinical Nutrition 2007; 85(2): $608 \mathrm{~S}-613 \mathrm{~S}$.

53. Kan E, Roberts G, Anderson PJ, Doyle LW. Victorian Infant Collaborative Study Group. The association of growth impairment with neurodevelopmental outcome at 8 years of age in very preterm children. Early Human Development 2008; 84: 409-16 http://dx.doi.org/10.1016/j.earlhumdev.2007.1 1.002

54. Ong KK. Catch-up growth in small for gestational age babies: good or bad? Current Opinion in Endocrinology, Diabetes and Obesity 2007; 4: 30-4.

http://dx.doi.org/10.1097/MED.0b013e328013 da6c

55. Law CM, Shiell AW, Newsome CA, et al. Fetal, infant, and childhood growth and adult blood pressure: a longitudinal study from birth to 22 years of age. Circulation 2002; 105: 1088-92.

http://dx.doi.org/10.1161/hc0902.104677

56. Ong KK, Ahmed ML, Emmett PM et al. Association between postnatal catch-up growth and obesity in childhood: prospective cohort study. British Medical Journal 2000; 320: 967-71.

http://dx.doi.org/10.1136/bmj.320.7240.967

57. Rolfe EL, Loos RJ, Druet C et al. Association between birth weight and visceral fat in adults. American Journal of Clinical Nutrition 2010; 92:347-52.

http://dx.doi.org/10.3945/ajen.2010.29247

58. Ong KK, Loos RJ. Rapid infancy weight gain and subsequent obesity: systematic reviews and hopeful suggestions. Acta Paediatrica 2006: 95(8): 904-8.

http://dx.doi.org/10.1080/08035250600719754
59. Baird J, Fisher D, Lucas P et al. Being big or growing fast: systematic review of size and growth in infancy and later obesity. British Medical Journal 2005; 331(7522): 929.. http://dx.doi.org/10.1136/bmj.38586.411273.E 0

60. Monteiro PO, Victora CG. Rapid growth in infancy and childhood and obesity in later life: a systematic review. Obes. Rev. 2005; 6: 14354.

http://dx.doi.org/10.1111/j.1467789X.2005.00 183.x

61. Singhal A, Fewtrell M, Cole TJ, Lucas A. Low nutrient intake and early growth for later insulin resistance in adolescents born preterm. Lancet 2003; 361:1089-97.

http://dx.doi.org/10.1016/S01406736(03)1289 $5-4$

62. Wells JC, Chomtho S, Fewtrell MS. Programming of body composition by early growth and nutrition. Proceedings of the Nutrition Society 2007; 66: 423-34. http://dx.doi.org/10.1017/S0029665107005691

63. Simeoni U, Ligi I, Buffat C, Boubred F. Adverse consequences of accelerated neonatal growth: cardiovascular and renal issues. Paediatric Nephrology 2011; 26: 493-508. http://dx.doi.org/10.1007/s00467-010-1648-1

64. Demmelmair H Long term consequences of early nutrition. Early Human Development 2006; 82(8): 567-74. http://dx.doi.org/10.1016/j.earlhumdev.2006.0 7.004 